PERSPECTIVA TEOLÓGICA ADERE A UMA LICENÇA CREATIVE COMMONS ATRIBUIÇÃO 4.0 INTERNACIONAL - (CC BY 4.0)

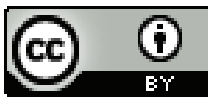

DOI: $10.20911 / 21768757 v 53 n 2 p 397 / 2021$

\title{
EMBRACING THE SPIRIT: THE IGNATIAN PNEUMATOLOGY OF LOUIS LALLEMANT
}

Acolhendo o Espírito: a pneumatologia inaciana de Louis Lallemant

André Brouillette *

\begin{abstract}
The Pneumatology of the Spiritual Exercises of St Ignatius of Loyola is famously discreet. However, other Ignatian authors give the Holy Spirit a central place in their spirituality. This article analyzes the Pneumatological contribution of Louis Lallemant's Spiritual Doctrine to Ignatian spirituality, in dialogue with the Spiritual Exercises. Anchored in the guidance of the Holy Spirit, this spiritual teaching advocates a docility to the Spirit nurtured by the "guard over the heart" and an on-going responsiveness to the Spirit's promptings. The "second conversion" promoted by Lallemant to his hearers is revealed as a Pneumatological event. It nonetheless conforms the believer to Christ, acknowledging the Christological focus of Ignatian Spirituality, while expanding its Pneumatological dimension.
\end{abstract}

KEYWORDS: Spiritual Exercises. Pneumatological. Louis Lallemant. Spiritual Doctrine.

RESUMO: A pneumatologia dos Exercícios Espirituais de Santo Inácio de Loyola é famosa por ser discreta. Entretanto, outros autores inacianos conferem ao Espírito Santo lugar central na espiritualidade. Este artigo analisa a contribuição pneumatológica da obra "Doutrina Espiritual" de Louis Lallemant para a espiritualidade inaciana, em diálogo com os Exercícios Espirituais. Fundamentada na condução pelo Espírito Santo, a obra de Lallemant preconiza uma docilidade ao Espírito alimentada pela "vigilância sobre o coração" e uma contínua capacidade de resposta aos apelos do Espírito. A "segunda conversão" proposta por Lallemant

\footnotetext{
"Boston College School of Theology and Ministry, Massachusetts, United States of America.
} 
a seus leitores é mostrada ali como um evento pneumatológico. No entanto, ela configura o crente a Cristo, reconhecendo assim o foco cristológico da espiritualidade inaciana ao mesmo tempo que expande sua dimensão pneumatológica.

PALAVRAS-CHAVE: Exercícios Espirituais. Pneumatológico. Louis Lallemant. Doutrina Espiritual.

\section{Introduction}

Come Holy Spirit... The elusiveness of the person of the Holy Spirit and the Pneumatological deficit of Western theology have long been lamented. The creed of the Council of Nicaea (325) listed the Holy Spirit alongside the Father and the Son, but left the task open for a further council to complete its definition. On the mystical side of Christian life, however, the presence and action of the Spirit has long been a source of hope (and suspicion!). Prophets, contemplatives, mystics, and charismatics have been hailed as saints or heretics because of the newness, creativity, and inspiration that the Spirit brings. As the traditional hymn of the Veni Sancte Spiritus reminds us, the Spirit is the one prayed to "come," to be present in the heart of believers and transform them. A seeming absence, or discreet presence, warrants this call to come.

The foundational text of Ignatian spirituality, the Spiritual Exercises of St. Ignatius of Loyola, shows an uneasiness in the portrayal of the Holy Spirit, while not obliterating his presence. Other major authors in the Ignatian tradition probe with greater readiness the person and workings of the Holy Spirit. One such author is Louis Lallemant, a French tertianship instructor, whose Doctrine spirituelle gives a central place to the Holy Spirit, seen through the lens of his reception by the human being. While part of the Ignatian tradition, Lallemant develops this spirituality in a new direction, moving its focus to the attention to the quiet guidance of the Holy Spirit. Lallemant's work highlights the closeness and multifaceted involvement of the Spirit in the life of believers and their ability to receive the Spirit's guidance, to share in what is most essential of God, holiness, and to act in a way modelled after Christ. As such, Lallemant offers a compelling and original contribution to the Pneumatological reflection in Ignatian spirituality.

In this article, after an overview of the Pneumatology of the Spiritual Exercises, I will present Louis Lallemant and his Doctrine spirituelle. I will then explore its Pneumatology from the perspective of the role of the Spirit, then the human's side - as guidance of the Holy Spirit, garde du coeur, and second conversion - before looking at the Christological orientation of Lallemant's teaching on the Holy Spirit. 


\section{The Pneumatology of the Spiritual Exercises of Ignatius of Loyola}

Despite a title that alludes to the Spirit for the magnum opus of Ignatius of Loyola, explicit mention of the Holy Spirit is scarce in its pages. Most occurrences are in the mysteries of the life of Christ in which the Spirit's role is explicit in the Biblical texts. ${ }^{1}$ The "Rules to think with the Church" also contain two references (SpEx, n. 365). Furthermore, mentions of the "good spirit" (e.g., SpEx 32) or "spiritual" point discreetly in the direction of the Holy Spirit, but these references require further analysis. Victor Codina Mir talks of a "silent presence" of the Spirit in the Spiritual Exercises (2016). Beyond a Pneumatology that proves elusive, a more implicit one might be deciphered. ${ }^{2}$

The caution of Ignatius in implicating the Holy Spirit in the Spiritual Exercises can be traced back to his dealings with the Spanish Inquisition and the suspicion of alumbradismo looming over anyone claiming too strongly the action of the Holy Spirit. ${ }^{3}$ Ignatius was also adamant about having his booklet approved by the Holy See and released as a public document despite its nature as handbook for the one giving the Exercises. Ignatius was successful in that endeavor in 1548, but he exercised prudence to reach that goal. In his other writings, Ignatius mentions the Spirit, and most profusely in his Spiritual Diary, but overall, a certain discretion towards the Spirit has to be acknowledged. ${ }^{4}$

The first place to look for the role of the Holy Spirit according to the Spiritual Exercises is the discernment of spirits. The rules of discernment of spirits (SpEx, n. 313-336) build up a grammar of the action of God revealing the language of the Spirit. While in the text of the Spiritual Exercises the claim of the action of the Spirit of God is subdued under the "good spirit," Ignatius' autograph Directory of the Spiritual Exercises states the indubitable connection between consolation - as the primary element

\footnotetext{
${ }^{1}$ Spiritual Exercises n. 263, 273, 304, 307, 312. As is customary for the Spiritual Exercises (SpEx), references are given to the paragraph numbers.

2 See in that regard the recent contribution of Bert Daelemans (B. DAELEMANS, SJ. Unción del Espíritu Santo' [Co 414] En el cruce de voluntades: pneumatología ignacian." In: Dogmática Ignaciana: buscar y hallar la voluntad divina [Ej 1]. Edited by G. URÍB ARRI BILBAO, SJ. Bilbao: Mensajero; Universidad Pontificia Comillas: Sal Terrae, 2018. p. 205240. (Series Manresa 67).

${ }^{3}$ Ignatius had to answer of his doctrine and way of life before religious authorities while he studied in Alcala and Salamanca (Testament or Autobiography) §§ 58-62 (Alcala), § 64-70 (Salamanca). See IGNATIUS OF LOYOLA, Personal Writings. London: Penguin Books, 1997. p. 41-48.

${ }^{4}$ Ignatius mentions the Holy Spirit in the Formula of the Institute (3 times), the Constitutions (10 times), the Spiritual Diary (about 20 times), the Directories (44 times), and more than 100 times in the Letters (DAELEMANS, 2018, p. 207).
} 
of the grammar of discernment - and the Holy Spirit. It mentions that the director should explain, "what consolation is, [...] all its aspects, viz., inner peace, spiritual joy, hope, faith, love, tears, and elevation of mind, all of which are gifts of the Holy Spirit." ${ }^{5}$ Ignatius was drawing on the fruit of the Spirit delineated by Paul in Galatians 5:22-23. In the divine economy, consolation pertains to the work of the Holy Spirit - although it could also be counterfeited by the evil one (SpEx, n. 331). Hence the fundamental element of the grammar of God's language, consolation, is spoken by the Holy Spirit. This fundamental element is described in the Spiritual Exercises first as an interior movement that leads one to become inflamed with the love of God (SpEx, n. 316), and is accompanied by sensible signs of increase of hope, faith, and charity, interior happiness, quiet and peace, or even tears leading to love of God. It is then contrasted with its opposite, spiritual desolation (SpEx, n. 317). Both definitions are preceded by the general way of proceeding of the "good spirit" and the "enemy"6 with regard to those who are progressing toward God (SpEx, n. 315) versus those who are moving in the wrong direction, away from God (SpEx, n. 314). Ignatius continues with advice about how to behave in time of desolation (SpEx, n. 318-322), and in time of consolation (SpEx, n. 323-324), and reveals some tactics of the enemy (SpEx, n. 325-327). A second series of rules dealing with more subtle matter (SpEx, n. 329-336) reasserts that it is characteristic of God to bring "true gladness and spiritual joy" (SpEx, n. 329). The attention is always directed at the interiority and at the traces left from inner movements. The language of the Spirit delineated there requires attention to these inner movements, their origin, their unfolding, their end, and the traces left, to discern in them the potential action of God in light of the Pauline categorization of the fruit(s) of the Spirit - especially in joy, love, and peace.

In the Spiritual Exercises, the discernment throughout the retreat with the help of the rules of discernment culminates in the election (SpEx, n. 169-189) as the embodiment of one's call to discipleship. The election can be reached with greater or lesser clarity, the light of the Spirit being overwhelming or the decision left to human faculties on their own (SpEx, n. 175-177). ${ }^{7}$ The

\footnotetext{
5 "Autograph Directory of St. Ignatius." In: On Giving the Spiritual Exercises: the Early Jesuit Manuscript Directories and the Official Directory of 1599. Edited by M. E. PALMER, SJ, St. Louis: The Institute of Jesuit Sources, 1996. §11, p. 8.

${ }^{6}$ This is Ignatius' vocabulary. These two principles (good spirit/bad spirit) are not perfect mirror of each other, since only the "good spirit" creates, edifies, whereas the "enemy" hinders or destroys. Other thoughts simply come from oneself.

${ }^{7}$ In the first degree, the Lord moves the will in such a way that there is no space for doubt regarding God's will (SpEx 175). In the second degree, clarity and knowledge is reached through the experience of consolation and desolation and the discernment of spirits (SpEx, n. 176). The third degree is a "quiet" one, in which the human faculties, while considering the general horizon of God's will for humanity, are not animated by a supernatural help (SpEx, n. 175).
} 
Pneumatological element is at the service of the incarnational dimension; it leads to decision and, eventually, to action. In this regard, it is appropriate that the process is articulated by an encounter with Christ through the Ignatian meditations of the Incarnation (SpEx, n. 101-109), the Call of the King (SpEx, n. 91-98) and the Two Standards (SpEx, n. 136-147), followed by his life and ministry, in what is called the second week. God has only one Face, one Word. Just as the Spirit was the animating principle of Jesus throughout his life, the Spirit discreetly leads retreatants to discern their way of embodying a commitment in the footsteps of Christ. The third and fourth weeks, bringing forth the passion, death, and resurrection of Christ, act as confirmation of the election made. Additionally, Jose Maria Lera considers the final contemplatio ad amorem (SpEx, n. 230-237) the "Ignatian Pentecost," ${ }^{8}$ since the last week of the Exercises contains only appearances of the risen Lord prior to the Pentecost event related in Acts. As such, it leaves open the stage for the pentecostal empowerment of contemporary disciples rooted in the call for a grounding in love of the contemplatio ad amorem, a love leading them to service. For his part, Bart Daelemans reads the Pneumatological element of Ignatian spirituality mostly through a "cruce de voluntades," at the encounter of one's will with that of Christ, in the Holy Spirit. (Daelemans, 2018, p. 235.240).

While the paradigmatic 30-day retreat was for Ignatius a once-in-a-lifetime event, some of its features were meant to potentially structure the life of the retreatants beyond the retreat. The practice of the daily examen (SpEx, n. 24-43) and the discernment of spirits both suggest the on-going role of the Spirit in the life of the disciple. Moreover, through his Spiritual Diary, the Constitutions, and the Letters, Ignatius offers further instances of action by the Holy Spirit or call on him. The discretion of the Spirit is not synonymous with an absence.

\section{Louis Lallemant and his Spiritual Doctrine}

French Jesuit Louis Lallemant (1588-1635) was master of novices in Rouen from 1622 to 1626, and tertianship instructor from 1628 to 1631. Such positions underscore the confidence that Jesuit authorities were placing in him, recognizing his spiritual mastery, and his ability to guide young men beginning their formation journey, and young priests ready to embark on their apostolic journey as formed members of the Society of Jesus. Both offices require a significant knowledge of Ignatius' Spiritual Exercises since the full 30-day version of the retreat is prescribed for each of these formation

${ }^{8}$ See J. M. LERA MONREAL, La pneumatología de los Ejercicios espirituales: Una teología de la cruz traducida a la vida. Bilbao: Mensajero/Universidad Pontificia Comillas/Sal Terrae, 2016. p. 114-148. (Series Manresa, 58). 
moments. Hence, Lallemant was a man entrusted with a tradition, and since it is a living one, he would rightly bring his contribution, integrating other spiritual accents and influences. ${ }^{9}$ Lallemant met and influenced well-known Jesuit saints, the North American Martyrs Isaac Jogues, Antoine Daniel, and Jean de Brébeuf, as well as the mystic Jean-Joseph Surin, among others. Lallemant's maturity corresponds to a time of acute debates among Jesuits in France about the proper place of interiority and activity in the spirit of the Society of Jesus, and new devotions among some mystically inclined young Jesuits. ${ }^{10}$ In that context, despite the prominent offices he held, Lallemant had his share of detractors who perceived him as too mystical.

The Doctrine spirituelle, the only significant work by Lallemant, is constituted by notes taken by his tertian Jean Rigoleuc - himself a notable spiritual figure in $17^{\text {th }}$ century France. ${ }^{11}$ The faithfulness of the current text to Lallemant's thought - with regard to potential changes introduced by Rigoleuc - has been the object of scholarly debate, especially around the section on the "garde du coeur". ${ }^{12}$ Father Pierre Champion published the Spiritual Doctrine in 1694, using Rigoleuc's notes, almost 60 years after Lallemant's death. The Spiritual Doctrine has garnered interest in the French-speaking academy in the last hundred years, most prominently with Henri Bremond, who identified a "school" of spirituality around Lallemant, ${ }^{13}$. Three main editions of the Doctrine were published in the

\footnotetext{
${ }^{9}$ Lallemant mentions for example the Carmelite mystic St. Teresa of Avila a dozen times in the Spiritual Doctrine. She had been canonized a few years prior with Ignatius and Francis Xavier. In addition to Jesuit spiritual authors posterior to Ignatius, Salin mentions possible influences from the Flemish mystical tradition, mediated by Hendrik Herp (D. SALIN. Introductio. In : L. LALLEMANT. Doctrine spirituelle. Edited by D. SALIN, SJ. Paris: Desclée de Brouwer, 2011. p. 31-32; see also T. BARTÓK. Un interprète et une interprétation de l'identité jésuite. Le père Louis Lallemant et sa Doctrine spirituelle au carrefour de l'histoire, de l'analyse institutionnelle et de la pensée d'auteurs jésuites antérieurs et contemporains. Rome: Gregorian \& Biblical Press, 2016, p. 297-298). Bartók's doctoral thesis is the most recent significant contribution to the scholarship on Lallemant, whom he approaches from a historical perspective.

${ }^{10}$ Historian Michel de Certeau explores this particular moment in the life of the Society of Jesus in France in light of the social context, and the connection between Lallemant and some of the young spiritual reformers (Michel DE CERTEAU. Crise sociale et réformisme spirituel au début du XVIIe siècle : une "nouvelle spiritualité » chez les jésuites français". Revue d'ascétique et de mystique, n. 41, p. 339-386, 1965).

${ }^{11}$ Rigoleuc was a missionary in Brittany, along with St. Julien Maunoir (1606-1683). In addition to the Spiritual Doctrine, a few letters of Lallemant survived.

${ }^{12}$ For the most current text in the original French, see L. Lallemant, 2011. The Salin edition includes important editorial choices in an attempt to retrieve the original Lallemant. I will use throughout its English translation as Spiritual Doctrine, referred to as "SD" (with the page number): L. LALLEMANT, The Spiritual Doctrine. Edited by Patricia M. RANUM, Boston: Institute of Jesuit Sources, 2016.

${ }^{13}$ Bremond devoted a volume of his opus magnum to Lallemant: H. BREMOND, Histoire littéraire du sentiment religieux en France : Depuis la fin des guerres de religion jusqu'à nos jours, Tome $V:$ La conquête mystique ${ }^{* * *}$ L'école du père Lallemant et la tradition mystique dans la Compagnie de Jésus, Paris : Bloud et Gay, 1920.
} 
same time span. ${ }^{14}$ Meanwhile, English speakers had to be content with a 1855 translation until the 2016 translation by Patricia Ranum for the Institute of Jesuit Sources, based on the 2011 French edition by Dominique Salin. Let us hope that this new translation will spur a renewed interest in Lallemant's spirituality, since, as Salin and Ranum claim with enthusiasm, it is a "the great classic of Ignatian spirituality."15

The Spiritual Doctrine originates in oral communications to a specific audience: young Jesuit priests who were experiencing the last part of their religious formation. They were living for a few months in a confined environment, but were soon to be missioned to various apostolates - to the tedium of schools for many of them. The audience was not of lay people or of pure contemplatives, but of men called to live in community and work in the world. Lallemant's audience was also not one of beginners. The "tertians," as the men completing the "third" year of novitiate are called, had been religious for many years, trained in prayer, and in obedience. They were to do the long retreat of the Spiritual Exercises for the second (and likely last) time in their life. They were beyond the initial fervor of youth, and intellectually cultivated by years of humanistic, philosophical, and theological studies. The ideal presented to them was an elevated one. It was also one aiming at nourishing a spirit of interiority and a contemplative attitude for men whose life would be extremely active, and at risk of activism.

One central characteristic of the teaching of Lallemant is the important role of the Holy Spirit and his place of honor in the Doctrine. While clearly embedded in the Ignatian tradition, Lallemant explicates at great length the ways in which the Spirit - and docility to the Spirit - is the engine for reaching spiritual maturity and holiness - "perfection" in the language of $17^{\text {th }}$ century spirituality. The fourth and central "principle" of his Doctrine is devoted to the "Docility to the Holy Spirit." The heightened attention to the Spirit should not be read independently from the strong Christological emphasis of the Spiritual Exercises - which are presupposed in the formation dispensed by Lallemant. ${ }^{16}$ It actually serves as a welcome counterpoint to an exclusive focus on the second Person of the Trinity. Lallemant's Pneumatology is oriented toward a Christology, fulfilling Yves Congar's axiom that a sound Pneumatology has a Christological point of reference (1997, v. 2, p. 35).

\footnotetext{
${ }^{14}$ The editors were Aloÿs Pottier in 1936, François Courel in 1959, and Dominique Salin in 2011.

${ }^{15}$ RANUM/SALIN, "Introduction" in SD, p. 1 (see LALLEMANT, 2011, p. 7).

${ }^{16}$ Drawing on Louis Cognet, Salin discerns a "weakening of Christological reflection" common to French spiritual authors of the $17^{\text {th }}$ century (SALIN, 2011, p. 36n51), in which the incarnational dimension of Christology gains more prominence over the redemptive one. However, a greater emphasis on the role of the Spirit is not ipso facto detrimental to the strength of Christology.
} 
The Doctrine does not offer "the" Ignatian Pneumatology, but certainly a profoundly Ignatian one, more explicit than that of Ignatius himself. Not the Ignatian Pneumatology, but an Ignatian Pneumatology. Commentators are quick to acknowledge that Lallemant's Pneumatology is not revolutionary, since it relies in its more didactic parts on the treatment of the Spirit by the likes of Thomas Aquinas. (Bartók, 2016, p. 564). ${ }^{17}$ Nonetheless, his originality lies in the integration of his treatment of the Spirit within his own spiritual teaching, as exemplified by the constant return to the theme of the purity of heart. There is a certain harmony in Lallemant's system, underscored by the entanglement of key elements - Holy Spirit, heart, and interiority - leading to a theology of the Holy Spirit with its own accents.

\section{The Spirit as Consoler, Pray-er, and Giver}

Lallemant details the multifaceted agency of the Holy Spirit in a way that Ignatius does not. The action of the Spirit can be seen as direct intervention in the life of believers (as Consoler or Enlightener), as enabler of prayer, and as bestower of gifts and fruits.

The first office that Lallemant ascribes to the Spirit is that of Consoler (SD, p. 125). A Johannine theme (John 16,7), it pertains to the realm of interiority that permeates the Spiritual Doctrine. It also highlights the intimacy of the action of the Spirit. As Consoler, the Spirit comforts in the uncertainty of salvation and during temptations (SD, p. 125-126), and offers consolation during the earthly exile (SD, p. 126), when the weight of the soul's longing to be filled by God is more acute.

Lallemant also uses other direct images to show the Spirit's action. Evoking the liturgical hymn Veni Sancte Spiritus sung at Pentecost (SD, p. 123n13), Lallemant notes that the "attribute [of the Holy Spirit] is to light, to direct, and to warm" (SD, p. 123). The guidance of the Spirit is the other side of the coin of the faithful's "docility to the Holy Spirit". The light bestowed by the Spirit to guide human action comes under the guise of the gifts of the Spirit in addition to the lights of reason, faith, and supernatural prudence (SD, p. 128).

Furthermore, Lallemant explicates the role of the Spirit in prayer, calling to the fore Carmelite mystic Teresa of Avila in particular for the language

\footnotetext{
${ }^{17}$ Bartók acknowledges the careful work of Roland Denis who analyzed in depth the dependence of Lallemant on thomistic questiones (BARTÓK, 2016, p. 564, referring to R. DENIS, La docilité à la conduite du St.-Esprit selon le P. Louis Lallemant, S.J. (comparaison avec St. Thomas). Dissertatio ad lauream, Rome: Angelicum, 1957). A good starting point is the discussion on the gifts of the Holy Spirit in the Summa Theologica, I-II, qu. 68. Chapters 3 to 5 of Lallemant's fourth principle consist in a presentation of the gifts, then the fruits, of the Holy Spirit (SD, p. 126-166).
} 
of contemplation. ${ }^{18}$ Contemplation is an "act of the supernatural habits that are called gifts of the Holy Spirit" (SD, p. 269). ${ }^{19}$ The will is absorbing all the soul's strength, since it is possessed by the Spirit of God (SD, p. 271). In rapture, or ecstasy, a sudden transport by the power of the Holy Spirit is achieved that causes, in Teresian vocabulary, a "flight of the spirit" (SD, p. 271). While these extraordinary phenomena should not be asked for, the gifts and guidance of the Holy Spirit, solid virtues, and excellent prayer should be (SD, p. 273), since they are the foundation for a life of perfection. Pragmatically, Lallemant advises to ask the Holy Spirit for the help of his grace at the beginning of prayer (SD, p. 240). This petition grounds the Pneumatological framework of any prayer. The Holy Spirit is not simply a visitor to the pray-er, for he "resides" in the heart (SD, p. 263). In silent prayer, one is never to resist the movements of the Spirit (SD, p. 257), following these holy promptings with great fidelity (SD, p. 263). The assent to such guidance in prayer prepares the individual for the Spirit's guidance at all times.

Drawing on a traditional theology, Lallemant devotes many pages of his fourth principle on the Docility to the Holy Spirit to a presentation of the seven gifts of the Spirit (SD, p. 131-161 $)^{20}$. The gifts of the Holy Spirit build on the virtues, and go beyond them (SD, p. 128) ${ }^{21}$. The gifts grow alongside charity (SD, p. 128), ${ }^{22}$ which is also the first fruit of the Spirit and the Spirit's very nature. When one is not perfectly endowed with the gifts of the Spirit, it remains especially important to practice virtue (SD, p. 129), in which the gifts find their soil. Any person in a state of grace has the gifts of the Holy Spirit (SD, p. 130), though the acts they should produce could be impeded by the venial sins that keep them bound (SD, p. 131). The examen of one's purity of heart is thus paramount. The gifts help to free saints from their slavery to creatures, affections, and distractions (SD, p. 129), in order that they reach sovereign peace and the freedom rightly theirs as God's children. The "grand conversions of princes and kings," show the suddenness and the strength of the Spirit's action that can break ties and reorient lives to the cross (SD, p. 128-129). Grace appears as overflowing, for in the case of the gift of science,

18 The internal connection with the Carmelite's understanding of contemplation is quite striking, even beyond borrowing the language. It clearly does not refer to the imaginative contemplation tradition of the Spiritual Exercises.

${ }^{19}$ Lallemant singles out in this case intelligence, wisdom and science contributing to the understanding, and piety and fear to the will (SD, p. 270).

${ }^{20}$ Wisdom, intelligence, science, counsel, piety, strength, fear of God. The presentation by Lallemant mixes definitions and scholastic explanations with practical advice, often circling back to the purity of heart.

${ }^{21}$ Lallemant uses there the metaphor of what sailing is to rowing to express the relation of gifts to virtues.

${ }_{22}$ "The gifts do not survive in the soul without charity; and as grace progressively grows, they too grow. That is why they are very rare and do not reach a high degree of excellence without a fervent and perfect charity [...]" (SD, p. 128). 
In vain does one do so much reading, and in vain does one read so many books in order to acquire the science of the interior life: the unction and the light that teach it come from on high. A pure soul will learn more about it in a month by the infusion of grace than others will learn in several years by the labor of studying." (SD, p. 145) ${ }^{23}$

Throughout his presentation of the gifts of the Holy Spirit, Lallemant is especially attentive to making connections with examples from saints, from both the perspective of interiorization and empowerment. Reflecting on the gift of wisdom - aimed at a knowledge of God (SD, p. 132) - Lallemant expresses the deep and unsuspected intimacy that the human spirit can reach with God in knowledge and movement:

For as a soul gradually purifies the spirit, the spirit becomes stronger and more capable of sustaining divine operations without emotion or suspension of the senses, as did Our Lord, the Blessed Virgin, the apostles, and a few other saints, whose spirits were always occupied with the most sublime knowledge, with marvelous interior transports, but with nothing appearing on the outside in the form of raptures and ecstasies. (SD, p. 133)

This interiorization of the Spirit's gifts can also be seen in the gift of intelligence as light given "to penetrate intimately the obscure truths proposed by faith" (SD, p. 137).

The empowerment - and even overpowering! - by the Spirit's gifts points in the direction of the outward/apostolic quality of the Spirit's action through individuals. Lallemant relates approvingly the story of one of his favorite saints, Vincent Ferrier (1350-1419), a Dominican renowned for his preaching skills:

It was through this gift [of science] that Saint Vincent Ferrier preached, with those prodigious successes we read about in the story of his life. He surrendered himself to the Holy Spirit, be it to prepare his sermons or be it to declaim them, and everyone came out moved. It was easy to see that the Holy Spirit was animating him and was speaking through his lips. One day, when he was supposed to preach before a prince, he thought he should give more study and more human diligence to preparing his sermon. He worked exceptionally hard on it; but neither the prince nor the rest of the listeners were as satisfied with this studied preaching as they were the next day, when he spoke as usual according to the movement of the Spirit of God. They pointed out to him the difference between these two sermons. That is because, he said, yesterday Brother Vincent preached, and today it was the Holy Spirit. (SD, p. 142-143) ${ }^{24}$

\footnotetext{
${ }^{23}$ Lallemant uses similar language about the overabundance of the Spirit's grace, since "by an effusion of his Spirit, [the Lord] give us more graces and help in prayer than acquired in several years of exterior actions, even those of zeal and charity" (SD, p. 231).

${ }^{24}$ Lallemant continues with a practical advice for a preacher: "Every preacher should be extremely dependent on the Spirit of God. The principal reparation for the pulpit is prayer and purity of heart" (SD, p. 143).
} 
This example comes in the context of the gift of science that gives a clear vision of one's individual conduct and that of others (SD, p. 141). The surrender of self to the Spirit, in this case, allowed St. Vincent to let the Spirit shine through him, marking the intimacy achieved through the sharing of the Spirit's gifts.

The action of the Spirit can be seen through the traces left as "fruits" of the Spirit. Lallemant treats briefly these twelve fruits (SD, p. 162-166). ${ }^{25}$ They are the natural point of connection with the concept of spiritual consolation in Ignatius. The traces can be used for discernment, as Lallemant does in the subsequent pages on "The Obstacles One Encounters on the Part of the Demon" (SD, p. 166-170) ${ }^{26}$ Lallemant highlights in particular the "peace and tranquility of the interior" since "God has joined together felicity and holiness, so that his graces not only sanctify the soul but in addition console it and fill it with peace and gentleness" (SD, p. 168). This is exactly what the demon tries to take away.

Most essentially, the Spirit is the one making the faithful participate in God's holiness. "[P]articipating in God's holiness is participating in what there is in him that is, so to speak, the most essential. The other attributes of God, such as science or power, can be communicated to men in such a manner that they are natural to them: holiness can never be natural to them" (SD, p. 163). Among the fruits of the Spirit demonstrating this participation, "Charity is first [...] because it most resembles the Holy Spirit, which is personal love; and charity consequently brings us closest to true and eternal felicity, and it gives us a more solid joy and a more profound peace" (SD, p. 163). In a lyrical riff on 1 Corinthians 13, Paul's hymn to charity, Lallemant ties together holiness and charity as worth more than anything else. ${ }^{27}$

\footnotetext{
${ }^{25}$ Charity, joy, peace, patience, gentleness, goodness, benignity, longanimity, faith, modesty, temperance, and chastity.

${ }^{26}$ Ranum sees that chapter as a "treatise on the discernment of spirits as taught by Saint Ignatius" (SD, p.166;119).

27 "Give a man empire over the universe, with the most absolute authority possible; let him possess all the riches, all the honors, all the pleasures one can desire; give him the most consummate wisdom you can imagine; let him be another Solomon, and more than Solomon; and let him not be ignorant of everything a spirit can know; add to that the power to work miracles: let him stop the sun, let him divide the seas, let him resuscitate the dead, let him participate in the power of God to as lofty a degree as you might wish; let him also have the gift of prophecy, the discernment of spirits, the knowledge of the secret of hearts. I say that the least degree of holiness which that man will have, the least action of charity that he will do, is worth more than all that; that it brings him closer to the sovereign good and gives him a more excellent being than all these other advantages would give him, if he had them." (SD, p. 163).
} 


\section{The guidance of the Holy Spirit and the "garde du coeur"}

The great originality of Lallemant's spirituality lies in the double concern for the purity of the heart and the guidance of the Holy Spirit. ${ }^{28}$ Lallemant himself elucidates that the two poles of spiritual life are the purging of the heart and the direction of the Holy Spirit (SD, p. 120). They are intrinsically interconnected since the purification of the heart allows for a more refined guidance by the Holy Spirit. They also illustrate the interplay of human and divine cooperation at the core of Lallemant's thought.

The essence of the spiritual and interior life consists of two things: on the one hand, the operations of God in the soul, the lights that illuminate understanding, and the inspirations that affect the will; and on the other, the soul's cooperation with the lights and the movements of grace. So that in order to deal with God and be disposed to receive from him the strongest and most frequent communications, it is necessary to have great purity of heart, great strength of spirit, a constant and inviolable fidelity to cooperating with God and following the movement of his Spirit, wherever it drives us. (SD, p. 171)

The purity of heart permits the guidance of the Holy Spirit in such a way that the Spirit directs the action of the individual:

The goal to which we should aspire, after we have exercised purity of heart for a long while, is to be so possessed and governed by the Holy Spirit that it is he alone who guides all our powers and all our senses, and who rules all our interior and exterior movements, and that we abandon ourselves entirely, by a spiritual renunciation of our wills and our own satisfactions. Thus we shall no longer live in ourselves, but in Jesus Christ (Ga 2:20) by a faithful correspondence with the operations of his divine Spirit, and by a perfect subjection of all our rebellions to the power of his grace. (SD, p. 121)

The goal, then, is for the human to reach a perfect responsiveness to the movements of the Spirit in oneself, in such a way as to let the divine Spirit take control and lead to life in Christ. On the part of the individual, a certain "nudity of spirit (nudité d'esprit)," where God "deprives us of his consolations and of sensible devotion in prayer and in other exercises in order to test our fidelity" creates a space in the soul that the Holy Spirit can fill with his gifts (SD, p. 100). ${ }^{29}$ The purity of the heart is also rooted in the "knowledge of ourselves and our wretchedness" (SD, p. 145), which is the foundation of the whole edifice of perfection. ${ }^{30}$ This deep sense of the

\footnotetext{
${ }^{28}$ Bremond makes of the "garde $d u$ coeur" and the guidance of the Holy Spirit two of the four main features of Lallemant's spirituality (BREMOND, 1920, p. 36f. and 46f.).

${ }^{29}$ The first lines of the Spiritual Doctrine launch the (Augustinian) theme of an emptiness that only God can fill (SD 49). The theme of the nudity of spirit and its corresponding emptying features prominently in the Rhineland mystical tradition, especially with Meister Eckhart. 30 "Now, it is a small thing to believe, and to know, that on our own we are nothing and can be nothing. [...] God wants us to have a knowledge of ourselves that is based on experience and perceptions $[\ldots]^{\prime \prime}$ (SD, p. 145).
} 
virtue of humility as the basis of the spiritual edifice is strongly attested in the teaching of Teresa of Avila as well. ${ }^{31}$ This self-knowledge and caution against oneself should remain, since the basis of any progress is to stand guard over the heart, "as on the first day" (SD, p. 145).

Lallemant defines "garde $d u$ cœur" (guard over the heart) as "nothing other than the attention one pays to the movements of one's own heart and to everything going on in the interior man, to regulate his conduct by the Spirit of God and adjust it to his duty and to the obligations of his station" (SD, p. 107-108). This constant attention to the inner movements in the heart is warranted by the desire to benefit from the supernatural help of the Spirit, for, "Our hearts are in a continual movement toward good, but it is always toward some natural good, unless the Holy Spirit lifts our hearts higher. Thus we should watch over all the movements of our hearts, in order to follow only those that come from the Holy Spirit" (SD, p. 102).

The guard over the heart suggests the necessary protection of the heart from negative influences. ${ }^{32}$ Ranum's choice of translating "garde" as "guard" underlines the almost military metaphor of protection, whereas a softer "attention" would have highlighted the conscious effort. ${ }^{33}$ The heart is a place where there should be only one love, since charity is what is closest to the Spirit (SD, p. 163). That love is only that of Jesus (SD, p. 212).

Lallemant himself contrasts his notion of the guard over the heart with the Ignatian examen, suggesting a development in a tradition. Salin speaks of Lallemant's innovation as a discernment in real time. (SALIN, 2011, p. 38). Indeed, Lallemant says that the garde $d u$ coeur, compared to the examen, is done in real-time (not at a given time), deals with current actions (not past ones), looks at details (and not simply broadly), and requires a moderate attention (not tiring the memory - SD, p. 108). Entering into this movement is not a given; "Some persons do not need the particular examen, because they do not commit the least fault without promptly being called on it

${ }^{31}$ Teresa's emphasis on humility is seen for example in the Way of Perfection, but even in the highest dwelling place of the Interior Castle (TERESA OF AVILA, Collected Works, Vol. 2, Translated by Kieran Kavanaugh, O.C.D., and Otilio Rodriguez, O.C.D., Washington: ICS Publications, 1980, see. e.g. Way of Perfection 4:4 (p. 54); 17 (p. 98-101), and Interior Castle 7M 4:8 (p. 447).

${ }^{32}$ Lallemant, in line with the rules of discernment of the Spiritual Exercises, sees the deleterious role of the demon trying to prevent the tertians' spiritual progress through trouble, chagrin, scruple, bad disposition, attachments, passions, etc. (SD, p. 166f.).

${ }^{33}$ SD 107n32. Military imagery is also used elsewhere, talking about the fruit of peace, that, "By sanctifying grace, God builds for himself in the soul a sort of citadel in which he is entrenched. By peace, he makes what might be called a sortie and seizes control of all the faculties, fortifying them so mightily that creatures can no longer come and trouble them" (SD, p. 164). 
and seeing it, always walking in the light of the Holy Spirit who guides them. These persons are rare and, so to speak, do a particular examen of everything" (SD, p. 160). Bartók suggests that Lallemant's notion reminisces that of nepsis found in the Desert Fathers. (2017, p. 43).

The guard aims at letting attention to the movements of the Spirit in one's heart become second nature. As a constant source of inspiration, the Spirit is to be seized in its immediate communication, and not only at particular times of spiritual retreat, in prayer, or a posteriori.

The assistance of the Holy Spirit is asked for by the believer, evoking especially the Spirit's gift of counsel:

In the morning, it is necessary to ask the Holy Spirit for assistance in all the actions of the day, humbly recognizing our ignorance and our weakness, and affirming that we will follow his guidance with a full and entire submission of spirit and heart.

Then, as we begin each action, it is necessary to ask again for the light of the Holy Spirit, in order to do it well; and at the end, to beg pardon for the faults one may have committed when doing it. In this manner, throughout the entire day one keeps oneself dependent on God, who alone knows the specific occurrences in which we are going to find ourselves and consequently can guide us more surely on every occasion by his counsel than by all the other lights, be they the lights of faith or the lights of the other gifts that do not descend as far as the level of specific cases. (SD, p. 148)

The gift of counsel is directed towards specific actions, showing what should be done in a specific time and place (SD, p. 147). As such, it is a guidance that is especially appropriate for those professing the guard over the heart.

The guard over the heart and the purity of conscience to the movements of the Spirit can be turned into a fateful commitment to always do God's will. ${ }^{34}$ In the passage just quoted, a daily affirmation to follow entirely the Spirit's guidance is advocated. Moreover, I suggest that the "voeu du plus parfait" (vow of the most perfect) professed by some of Lallemant's tertians and Lallemant himself. (Armogathe, 1993, p. 40-41) 35 $^{35}$ the logical extension of the doctrine of docility to the Spirit. ${ }^{36}$ Ignatius mentions in the Spiritual Exercises that a good deed done because of a vow is more

\footnotetext{
${ }^{34}$ Lallemant distinguishes between the will signified by the commandments (that binds everyone) and the inspirations, and the will of "bon plaisir" which is manifested in events (see SD, p. 117n2).

${ }^{35}$ Jean de Brébeuf, the famous North American martyr, also made that vow on 18 August 1645. Joseph Creusen highlights the prominence of the example of St. Teresa of Avila when this vow is discussed (CREUSEN, 1933, p. 621-643).

${ }^{36}$ Lallemant is aware that "There are very few persons who do everything they can do for God and for their neighbor" (SD, p. 158), often because of omissions rooted in fear.
} 
meritorious than without one (SpEx 14). This vow entails to do what is perceived as being God's will, even through a simple inkling, in this particular place and time. It does not depend on doing an objectively more perfect action, but on subjectively refusing nothing of God's inspirations. It presupposes a great acuity in the Pneumatological acoustics of the heart, which is exactly what Lallemant promotes through the guard over the heart and the docility to the Holy Spirit.

\section{The "second conversion" as a dive into the Spirit}

The theme of the "second conversion," sometimes identified as "franchir le pas" (to "take the plunge" - SD, p. 57) is one of the central features of Lallemant's spirituality. ${ }^{37}$ Lallemant introduces the theme in his second principle, on the idea of perfection, while lamenting our years-long fight against God and "resistance to the movements of his grace" (SD, p. 57). "[I]t is necessary," writes Lallemant "only to renounce, once and for all, all our self-interests and all our satisfactions, all our plans and all our wishes, in order to depend henceforth solely on God's bon plaisir and to put ourselves totally in his hands" (SD, p. 57). It is worth remembering that Lallemant was speaking to proven Jesuit priests enjoying their last stretch of spiritual formation; his exhortation was to have them refuse half-measures, capitalizing on this opportunity to make the extra step and renew in a mature way their dedication.

Lallemant sees in the second conversion a hallmark of the spiritual life for exemplary figures:

For the majority of saints and for the religious who are making themselves perfect, what usually happens are two conversions: one by which they devote themselves to God's service, the other by which they devote themselves entirely to perfection. That can be observed in the apostles, when Our Lord called them and when he sent them the Holy Spirit; in Saint Teresa and in her confessor, Father Álvarez, and in several others. This second conversion does not come to every religious, and that is owing to their negligence. For us, the time for this conversion is commonly during the third year of novitiate. (SD, p. 81)

The dedication to religious life - "God's service" in this case - marks the first conversion, from the world to God's perspective. The second conversion is one of entirety and perfection. The fault for not attaining this second conversion is clearly put on the religious themselves, underlining the importance of one's commitment. This is reinforced with the mention

${ }^{37}$ Henri Bremond, in particular, highlighted this contribution by making it into the first of the four main features of this spirituality (BREMOND, 1920, p. 13f.), though Lallemant does not separately expose it, unlike the guard over the heart or the docility to the Holy Spirit. 
that now is the time of this second conversion for his hearers. A very important element for our Pneumatological research is the analogy of the two conversions for the apostles: the call by Christ and the sending of the Spirit. The first launched them on a different life path, whereas the second connected the apostles to the guidance of the Holy Spirit. ${ }^{38}$ By such a link, the theme of the second conversion becomes eminently Pneumatological. The change in the second conversion is a radical turning to the guidance of the Spirit. As dependence on the Spirit, it would mean to give the Spirit full use of one's faculties and being (SD, p. 213). The second conversion is a dive into the Spirit.

\section{The Spirit molding the faithful to Christ}

Ignatian spirituality, through the Spiritual Exercises of Ignatius of Loyola, has a strong Christological framework. Given the tertians' experience of the 30-day retreat and their commitment as Christians and Companions of Jesus, an assumed orientation toward Christ of the Spiritual Doctrine is not be surprising. Despite the centrality of the role of the Spirit for Lallemant, the Spirit is not disconnected from Christ and essentially leads to him, in molding the faithful to him. The Spirit, even when exalted, is always oriented toward Christ. ${ }^{39}$ The love the Spirit lights in hearts is a love for Christ (SD, p. 208).

In its dogmatic understanding, the Pneumatology of Lallemant is traditional, aligning with creedal formulae. "[T]he Holy Spirit proceeds from the Father and the Son by way of will and love" (SD, p. 225), He spoke through the prophets and the apostles, and spoke most perfectly in the Incarnate Word (SD, p. 207). Jesus-Christ is the "principle of the Holy Spirit" (SD, p. 192) because the plenitude of divine Spirit was given to the Church after the coming of Christ in the world. Without dwelling on these creedal statements, Lallemant gives flesh to the relationship between the Son and the Spirit through the life of Christ and that of believers.

\footnotetext{
${ }^{38}$ One could think similarly of other analogies; in the life of Christ, the Incarnation vs. the Baptism, or in the sacramental life, Baptism vs. Confirmation.

${ }^{39}$ This Christological orientation of the Spirit is seen, for example, in the section on contemplation, in which the agency of the Spirit is paramount, but where Lallemant underlines that "souls belong to the Son of God" since he redeemed them (SD, p. 268). Similarly, while talking about the powerful gifts and actions of the Spirit, Lallemant notes they lead some to abandon everything and "devote themselves to the cross" (SD, p. 128), pointing in the direction of a Christological dimension in the action of the Spirit. Wisdom, as a gift of the Holy Spirit, is shown as "nothing other than this folly that savors only what Our Lord and the saints have savored. Now, Jesus Christ left a suave odor, a delicious aroma, on everything he touched during his mortal life, for example in poverty, in abjection, on the cross" (SD, p. 135), once again strengthening the Christological orientation of the gifts of the Spirit.
} 
The role of Christ as bestower of the Spirit is illustrated in Lallemant's understanding of the Eucharist, since he asserts that,

Frequent Communion is an excellent means of perfecting virtues in us and of acquiring the fruits of the Holy Spirit. For Our Lord, uniting his body to our bodies and his soul to our souls, burns and consumes in us the seeds of our vices and gradually communicates to us his divine moderation and his perfections, according to whether we are disposed and whether we allow him to operate. (SD, p. 162)

Lallemant continues by giving an example of what the Eucharistic Christ might encounter in the communicant, and what he would do, stating that,

He erases the memory and the image of this discontent; he destroys the imprint that had remained with us in all our powers, and he totally smothers those seeds of sin, putting in their place the fruits of charity, joy, peace, patience. In the same manner, he rips out the roots of anger, intemperance, and our other flaws, and he communicates the virtues and their fruits to us. (SD, p. 162-163)

In this passage, the bestowing of the gifts of the Spirit is placed firmly in the hands of Christ himself.

The orientation of the docility to the Spirit, by being attentive to his movements, is directed at interiority, and ultimately leading to action. Lallemant critiqued action ${ }^{40}$ insofar as he warned against an activism in today's vocabulary - not rooted in a deep interior life. The imitation of the Lord is first and foremost the imitation of his interior life (SD, p. 231), not simply a reproduction of his actions. In his discussion of the gift of science, Lallemant proposes Jesus Christ as "our model" since he "gave thirty years to the contemplative life and only three or four to what is called the mixed life" (SD, p. 144) $)^{41}$. Moreover, Lallemant notes that the gospels show the connection between the gifts of the Holy Spirit and the actions of the Lord (SD, p. 129). Therefore, in the life of Christ himself, the inner motion of the Spirit determined the external action. Imitation of the Lord is then congruent with attention to the Spirit. To be docile to the Holy Spirit means living in Christ: "[...] we shall no longer live in ourselves, but in Jesus Christ, by a faithful correspondence with the operations of his divine Spirit, and by a perfect subjection of all our rebellions to the power of his grace" (SD, p. 121). The "liberty of spirit" attained by removing any attachment and opening oneself to the guidance of the Holy Spirit "makes our interior conform to Jesus Christ's" (SD, p. 212). Nothing else but the will of God would be desired; "When one has

${ }^{40}$ This critique is one of Bremond's four features for Lallemant's spirituality (BREMOND, 1920, p. 26f.)

${ }^{41}$ Lallemant also gives as model "God himself, whose life, before time, was purely contemplative, being solely occupied with knowing himself and loving himself" (SD, p. 144). 
given one's heart to the love of Jesus, that love no longer tolerates either sentiment or personal will" (SD, p. 212). When our actions are done "by his Spirit," the Spirit of Christ, then they "bear the mark of resemblance to the Lord" (SD, p. 213), as opposed to self-love. In being led by the Spirit the faithful come to resemble Christ.

Since Christ is animated by the Spirit in his action, the faithful should also be guided by the same Spirit in their action, and Christ should be their model. The Holy Spirit,

governed the entire sequence and management of the actions of Jesus Christ in general, and of each action in particular. It was by this principle that the holy humanity operated the same things that it saw being operated in the divinity; the same effects of mercy, for example, of justice, gentleness, rigor, love, hate. So that the holy humanity was, so to speak, the seal of divinity where all the features of its prototype were imprinted, as much as humanity was capable of it. This was done by the direction of the Holy Spirit, who wanted to trace for us, in the life and actions of Jesus Christ, a way to guide us surely to glory and to the sovereign happiness of eternity. (SD, p. 196)

The Holy Spirit led the humanity of Christ to conform to the divinity, giving the faithful in the process an exemplar of the divine way to be human. ${ }^{42}$ Drawing a parallel between the role of the Spirit at the conception of Jesus and his role in guiding the conduct of Jesus, Lallemant states that the Holy Spirit should be not only the "principle of our spiritual regeneration in baptism," but also "the principle of our conduct; that he should govern us in all things, and that we should depend entirely on his direction, since the members ought to be animated by the same spirit as the head" (SD, p. 196).

The Holy Spirit spoke in the Incarnate Word "endlessly, ever more excellently, and with greater strength, $[\ldots]$ in the most perfect and strongest manner" (SD, p. 207). Thus, Lallemant advocates for a "special esteem and affection for the words of Our Lord that are reported in the Gospels" (SD, p. 207). ${ }^{43}$ The life and words of Christ offer a Spirit-filled model to our humanity. In his discussion of the gift of strength, which is given by the Spirit to "do and to suffer extraordinary things, to undertake the most difficult actions, to expose oneself to the most formidable dangers, to endure the most disagreeable pains, and to do it with perseverance and in a heroic manner" (SD, p. 154-155), Lallemant calls on the example of Christ. ${ }^{44}$ This gift can provide both miraculous strength in the body, and dispel all human fear in the spirit (SD, p. 156). The Christic example of

\footnotetext{
${ }^{42}$ From a different perspective, Lallemant lists among the signs of a deceived soul both the occupation in prayer of only the divinity of the Lord and not his humanity, as well as the lack of application to knowing and regulating the movements of one's heart (SD, p. 169). In concrete ways, it is through the humanity - of the Lord and ours - that the Spirit works. ${ }_{43}$ "All the other spiritual books are part grace and part nature. Reading the holy scripture is often a means of receiving the Holy Spirit and being guided by his direction" (SD, p. 138).
} 
spiritual strength is the episode of the agony in the garden, when Jesus "overcame the fear of his passion and his death and [rose] from prayer all aflame with zeal" (SD, p. 156). ${ }^{45}$

The saints are also located at the crux between guidance of the Spirit, imitation of Christ, and exemplarity for the faithful. Since it is the Spirit of Christ that empowers the faithful to do good, "All the good we do, it is Jesus Christ who is doing it in us" (SD, p. 207). The very principle of our action would be Christ himself in his Spirit. Lallemant applies the same logic to the saints when he writes,

One can say that, in a way, he [=Christ] did all the good works of the saints, because he gave them the thought about it, because he was the first to have the thought, and because he had it for them; because they only undertook these works as a result of the movement of his Spirit and because they only carried them out with the help of his grace. Therefore, when one celebrates the feast day of some saint, one celebrates the feast day of Jesus Christ, who is the author of all the holiness of the saints. (SD, p. 207)

While one could consider that this statement diminishes the role both of the individual saint and of the Spirit, another perspective would be to marvel at the participation of the saint in the very work of Christ in the Spirit, sharing in the very holiness of God.

Among the saints, Lallemant highlights two in particular. First, Mary, Mother of God, as "spouse of the Holy Spirit" (SD, p. 203), since she "contracted a sacred marriage with him in the name of all human nature" (SD, p. 203). Unlike all other human beings, Mary also never resisted the movements of the Spirit - something believers aim for. Second, Saint Joseph, who is a model of guidance from the Holy Spirit. Because of his docility to the Spirit, Joseph gained the task in life of "governing" (SD, p. 233) - no less - the Son of God and Virgin Mary, under the Spirit, and now, as patron saint of contemplatives, he has the "right to direct faithful souls interiorly" (SD, p. 233). Hence, the habitual presence and guidance of the Holy Spirit in these saints modelled them after the Holy One and even gave them the authority to direct others, as spouse or guardian, in lives oriented to Christ.

\section{Conclusion}

Lallemant's Pneumatology is not simply a repetition of Ignatius' own thoughts. They hold in common the practical dimension of their spirituality; theirs in a theology put in practice and nourished by exercise, not

\footnotetext{
${ }^{44}$ As examples for his tertians taken from Jesuit life, Lallemant mentions the foreign missions, risks to one's health, calumny, persecution, being "left for a long time laboring in the classrooms" (SD, p. 155).

${ }^{45}$ Lallemant then continues with examples of saints.
} 
simply professed. The emphasis of both is on the individual dimension, not on the collective one. However, while the Spiritual Exercises highlights discernment in light of the election, the Spiritual Doctrine stresses the on-going guidance of the Holy Spirit in the whole of life.

Louis Lallemant's Pneumatology is at once inspiring and vivid. It stresses the overwhelming presence and nearness of the Spirit in the believer's life. ${ }^{46}$ It focuses the attention to the movements of the Holy Spirit in the soul, and invites a docility to the minute guidance of the Spirit. This guidance leads from inspiration to action, being less focused on the decision - a choice already implied in the garde $d u$ coeur and the docility to the Spirit. It gives flesh to an alignment with and conformity to the will of God. This Pneumatology is also built not in terms of what is necessary for salvation, but is seen through the lens of perfection, of spiritual growth. The hoped-for "second conversion" is a conversion to a faithful dive into the Spirit.

The Spirit is of Christ, and leads to Christ. The configuration to Christ is achieved by the interior purity of the heart in human cooperation that mirrors Christ's inner life, since the Spirit resides in the heart. While Christ is the model of believers, the Spiritual Doctrine does not emphasize the contemplations of the life of Christ in the way the Spiritual Exercises does, moving from the imaginative contemplation to the interior movement. Rather, it grounds its Christic dimension right into the interiority of the soul in which the Spirit is to be found that propels the imitation of Christ.

Does the Spirit bring a creative newness in the world? Does the Spirit bring disruption? Or is the Spirit tamed in the embrace? Lallemant does not address such questions. The fruits of the Spirit are along the lines of peace, love, and joy in oneself. What is brought to the world when the faithful listen to the Spirit and act on the Spirit's guidance? Sometimes, it means preaching with fervor, audacious deeds, martyrdom, and even surprising conversions. One can only imagine what the Spirit wants to do and could do in our world!

\section{Abbreviations}

$\mathrm{SD}=$ Spiritual Doctrine

SpEx = Spiritual Exercises

\section{References}

ARMOGATHE, J.-R. Tradition ignatienne et «doctrine spirituelle» du P. Louis Lallemant. Études Normandes, v. 42, n. 4, p. 33-44, 1993.

\footnotetext{
46 The nearness and direct inspiration of God was expressed in the Annotation 15 of the Spiritual Exercises (SpEx 15) about letting creature and creator dialogue without interposition on the part of the person giving the Exercises.
} 
BARTÓK, T. Un interprète et une interprétation de l'identité jésuite. Le père Louis Lallemant et sa Doctrine spirituelle au carrefour de l'histoire, de l'analyse institutionnelle et de la pensée d'auteurs jésuites antérieurs et contemporains. Rome: Gregorian \& Biblical Press, 2016.

B ARTÓK, T. Louis Lallemant and Jesuit Spirituality. The Way, v. 56, n. 1, p. 31-44, 2017.

BARTÓK, T. Louis Lallemant and his Doctrine spirituelle: Myths and Facts. In: A Companion to Jesuit Mysticism. Edited by R. A. Maryks, Leiden/Boston: Brill, 2017. p. $112-138$.

BREMOND, H. Histoire littéraire du sentiment religieux en France. Depuis la fin des guerres de religion jusqu'à nos jours. La conquête mystique. L'école du père Lallemant et la tradition mystique dans la Compagnie de Jésus. Paris: Bloud et Gay, 1920. v. 5.

CERTEAU, M. de. Crise sociale et réformisme spirituel au début du XVIIe siècle. Une "nouvelle spiritualité » chez les jésuites français". Revue d'ascétique et de mystique, n. 41, p. 339-386, 1965.

CODINA V. A Silent Presence: the Holy Spirit in the Ignatian Exercises. Barcelona: Cristianisme I Justícia, 2016.

CONGAR, Y. I Believe in the Holy Spirit. New York: Crossroad, 1997.

CREUSEN, J. Le voeu du plus parfait. Nouvelle Revue Théologique, v. 60, n. 7, p. 621-643, 1933.

DAELEMANS, B. “'Unción del Espíritu Santo' [Co 414] En el cruce de voluntades: pneumatología ignaciana". In: Dogmática Ignaciana: buscar y hallar la voluntad divina [Ej 1]. Edited by G. URÍB ARRI BILB AO, SJ. Bilbao: Mensajero/Universidad Pontificia Comillas/Sal Terrae, 2018. p. 205-240. (Series Manresa 67).

IGNATIUS OF LOYOLA. Personal Writings, London: Penguin Books, 1997.

LALLEMANT, L. Doctrine spirituelle. Edited by D. Salin, SJ. Paris: Desclée de Brouwer, 2011.

LALLEMANT, L. The Spiritual Doctrine. Translated and edited by P. M. RANUM. Boston: Institute of Jesuit Sources, 2016.

LERA MONREAL, J. M. La pneumatología de los Ejercicios espirituales. Una teología de la cruz traducida a la vida. Bilbao: Mensajero/Universidad Pontificia Comillas/ Sal Terrae, 2016. (Series Manresa 67).

TERESA OF AVILA. Collected Works. Washington: ICS Publications, 1980. v. 2.

Article submitted on April, 022021 and accepted on August 052021.

André Brouillette SJ Ph.D., Université Laval. STD summa cum laude, Institut Catholique de Paris. Associate Professor of Systematic and Spiritual Theology (School of Theology and Ministry) Orcid.org/0000-0001-5667-6200. Contact: andre.brouillette@bc.edu

Address: 9 Lake St, Boston, Massachusetts 02135, United States of America. 